\title{
Problems and perspectives for Chagas disease control: in search of a realistic analysis
}

\author{
Problemas e perspectivas para o controle da doença de Chagas: \\ a busca de uma análise realística
}

\author{
João Carlos Pinto Dias ${ }^{1}$, Aluizio Prata ${ }^{2}$ and Dalmo Correia ${ }^{2}$
}

\begin{abstract}
Chagas disease was an important medical and social problem in almost all of Latin America throughout the twentieth century. It has been combated over a broad swath of this continent over recent decades, with very satisfactory results in terms of vector and transfusional transmission. Today, a surveillance stage still remains to be consolidated, in parallel with appropriate care required for some millions of infected individuals who are today living in endemic and non-endemic areas. Contradictorily, the good results attained have generated excessive optimism and even disregard among health authorities, in relation to this disease and its control. The loss of visibility and priority may be a logical consequence, particularly in Latin American healthcare systems that are still disorganized and overburdened due to insufficiencies of financial and human resources. Consolidation of the victories against Chagas disease is attainable but depends on political will and continual attention from the most consequential protagonists in this struggle, especially the Latin American scientific community.
\end{abstract}

Key-words: Chagas disease. Control. Perspectives.

\section{RESUMO}

Constituindo um importante problema medico e social de quase toda a América Latina por todo o século XX, a doença de Chagas tem sido combatida em ampla extensão do Continente nas últimas décadas, logrando-se resultados muito satisfatórios em termos de sua transmissão vetorial e transfusional. Atualmente há ainda uma etapa de vigilância a ser consolidada, em paralelo com a atenção adequada e necessária para alguns milhões de infectados que hoje vivem em áreas endêmicas e não endêmicas. Contraditoriamente, os logros alcançados têm gerado excesso de otimismo e mesmo descaso para com a doença e seu controle entre autoridades sanitárias. A perda de visibilidade e prioridade pode ser uma consequiência lógica, principalmente nos sistemas de saúde latino americanos, ainda desarticulados e assoberbados por poucos recursos financeiros e humanos. A consolidação das vitórias contra a doença de Chagas é viável, mas passará por vontade política e permanente atenção por parte dos mais conseqüentes protagonistas desta luta, especialmente os cientistas latino americanos.

Palavras-chaves: Doença de Chagas. Controle. Perspectivas.

Considering the enormous advances in human Chagas disease control observed over the last two decades, the health authorities declared in the recent WHO Resolution 51.14 that elimination of human Chagas disease can be achieved by 2010, by means of continuous control and pertinent surveillance in endemic areas. After analyzing this proposition, a panel formed by experts within the American Intergovernmental Initiative against American Trypanosomiasis decided to clarify the following points ${ }^{10}$ :

- Chagas disease is an endemic infectious disease that was formerly a primitive enzootic phenomenon and has undergone evolution in Latin America into a widespread anthropozoonosis. This disease lacks effective treatment in all its phases and no immunoprophylaxis is available. Moreover, the natural circulation of Trypanosoma cruzi is widely spread across sylvatic ecotopes all over the American continent. For these reasons, it cannot be considered eradicable, since eradication means the definitive interruption of the transmission, such that it is completely maintained in the absence of any control or surveillance action. On the other hand, elimination may be understood as the absence of transmission (or of a given vector species) within a given geographical space, and is dependent on maintaining continuous control and/or surveillance actions.

- Considering another angle, a residual contingent of at least 12 million individuals who are already infected continue living in endemic and non-endemic countries, thereby generating the possibility of new case production, by means of alternative mechanisms for Trypanosoma cruzi transmission, particularly through the congenital and transfusional routes.

1. Centro de Pesquisas René Rachou, Fundação Oswaldo Cruz, Belo Horizonte, MG. 2. Disciplina de Doenças Infecciosas e Parasitárias, Universidade Federal do Triângulo Mineiro, Uberaba, MG

Address to: Dr. João Carlos Pinto Dias. Centro de Pesquisas René Rachou/FIOCRUZ. Av. Augusto de Lima 1715, Barro Preto, $30190-002$ Belo Horizonte, MG.

Tel: $55313349-7700$

e-mail: jcpdias@cpqrr.fiocruz.br

Recebido para publicação em: 22/11/2007

Aceito em: 10/03/2008 
- In addition, the persistence of sylvatic foci has become increasingly correlated with so called oral transmission of human Chagas disease, with about 100 new cases reported yearly in different ecological situations.

- Nevertheless, over the last two decades, the transmission of human Chagas disease has been effectively controlled in several endemic areas, carried out by means of massive vector control activities followed by continued surveillance and by regular serological selection of blood donors.

- The interruption of parasite transmission to new generations, plus the dramatic reduction of domestic triatomine infestation in regions where measures have been implemented, has generated the pragmatic concept of elimination, which has a temporal and geographical meaning, since the control actions are maintained sustainably.

- In the particular case of introduced and restricted-circulation domestic triatomines (such as Triatoma infestans in several countries and Rhodnius prolixus in Central America and Mexico), the concept of elimination may also be applicable.

Our concern regarding human Chagas disease over the near future will depend on both political and scientific process, taking into account its ecological complexity and that its social burden is still very high. For practical purposes, human Chagas disease needs to be thought of as a neglected disease closely linked with human poverty. Thus, it might be addressed through the following three propositions: adequate attention, development policies and health policies ${ }^{610}$

In view of the poverty of the individuals under risk, the problem of sustainable control over the disease will basically be dependant on the overall public policies in endemic countries. The solution will not be simple, considering the complexity of the political context of Latin America. Therefore, the current affirmation concerning the elimination of Chagas disease in some endemic areas must be analyzed in accordance with the following possibilities and questions:

- Is it a realistic possibility?

- Does it mean a demagogic proposition?

- Does it represent untoward optimism?

- Could better results have a stimulating effect in countries where the disease is not yet under control?

- Could the proclamation of better results emulate the weakness of current control programs?

In reality, there are some reasons for answering yes to each of these questions, depending on a variety of circumstances. For instance, the epidemiological results observed in Brazil over recent years should be considered very positive in terms of Triatoma infestans elimination and blood bank control, with a substantial impact on reducing disease incidence. In such circumstances, the transmission of human Chagas disease has been minimized in this country, almost reaching the elimination point. The morbidity and mortality due to the disease have also been declining in this country ${ }^{2}$. For Latin America as a whole from 1990 to 2006, decreases in some epidemiological indicators (Table 1) have followed the implementation of objective control actions, as shown in a recent WHO workshop ${ }^{10}$ :

Table 1 - Changes in some epidemiological parameters following the interruption of Chagas disease transmission, 1999-2006 ${ }^{10}$.

\begin{tabular}{lccc}
\hline Epidemiologicalparameters & 1990 & 2000 & 2006 \\
\hline Annual deaths & $>45,000$ & 21,000 & 12,500 \\
Cases of human infection & 30 million & 18 million & 15 million \\
Annual incidence & 700,000 & 200,000 & 41,200 \\
Population at risk & 100 million & 40 million & 28 million \\
Distribution & 21 countries & 19 countries & 18 countries \\
\hline
\end{tabular}

Source: TDR/WHO, PAHO, WHO

These figures indicate that there has been a significant and consistent reduction in human Chagas disease transmission, basically in endemic areas that are under regular vector and blood bank control. Even so, significant epidemiological residual incidence and morbidity still exists. Since the theoretical idiomatic dilemma between Chagas disease eradication and elimination is nonexistent, the main problem for scientists and governments remains the sustainability of its control. There is a variety of evidence indicating that this is an attainable goal for additional endemic areas, since the main tools and strategies for accomplishing it are available. The current situation among the regional Latin American initiatives was recently summarized by Salvatella ${ }^{10}$ :

- Uruguay, Chile and Brazil present interruption of the main vector transmission through the country. Argentina, Paraguay and Bolivia present partial interruption.

- Guatemala, Honduras and El Salvador present areas from which Rhodnius prolixus has been eliminated.

- Central America presents varying degrees of control over Triatoma dimidiata.

- The Andean countries have Chagas programs in progress.

- The Amazonian surveillance system is in progress.

- The Mexican national Chagas program is in progress.

- For non-endemic countries, a new initiative is being proposed, to deal with the consequences of human migration and the possibility of transmission by means of congenital, blood transfusion and organ transplantation routes.

In public health terms, effective control over human Chagas disease is undoubtedly possible, but program actions need to be sustained over several years. To reinforce the optimistic perspectives, some data recorded in Brazil can be taken into consideration $^{2} 613$.

- The number of Triatoma infestans-positive municipalities decreased from 711 in 1980 to two or three in 2006.

- The proportion of triatomine foci inside homes decreased from $25 \%$ in 1980 to less than $2 \%$ in 2006.

- The proportion of controlled blood banks increased from $13 \%$ in 1980 to $99 \%$ in 2006 . 
- The proportion of blood donor candidates who have Chagas disease is progressively decreasing ( $4 \%$ in 1980 to $0.4 \%$ in 2006).

- The risk of congenital disease has usually been low and is tending to decrease because the number of infected fertile women is progressively decreasing.

From another angle, there are a variety of reasons why the control task remains unfinished, involving the consolidation of control activities in terms of program implementation as much as continuous surveillance ${ }^{6}{ }^{10}$. For example, in different Latin American regions, current data show that the work must be extended for several years more, because of different reasons such as:

- The large number of enzootic cycles that exist across the continent, including sylvatic foci of Triatoma infestans in some parts of Bolivia.

- The existence of at least eight or nine secondary vector species that can colonize human dwellings, chiefly in Brazil and Mexico.

- The occurrence of ecological difficulties regarding vector control in several parts of the continent, such as in the Chaco and Amazon regions.

- The detection of vector resistance against the current pyrethroid insecticides in some Argentine and Bolivian regions.

- The occurrence of home invasion and disease transmission by adult vectors, without colonization, in some regions of Panama, Ecuador and Brazil.

- The existence of at least two million infected individuals who need medical and social attention and can transmit the disease along the whole length of different alternative epidemiological routes.

- The detection of more than 100 new acute cases per year, resulting from an oral transmission mechanism.

Taking these points together, the central questions seem to remain political will, sustainable control program and technical expertise. Additional research is required to deal with some problems of control improvement and some new epidemiological situations, as well as unpredictable occurrences of oral transmission $^{5612}$. A responsible attitude is required from the scientific community. This is still unfinished business and much remains to be done. The greatest danger in such good news lies in undue triumphalism and the slackening of control measures. Furthermore, it must be remembered that the decentralization of health programs throughout Latin America, over the last twenty years, has radically transformed the classical vertical vector control activities in municipal programs. An additional problem arises from this decentralized model, since generally the municipalities have not tradition in vector control and epidemiological surveillance. In such circumstances, very strong central and subregional technical teams are required in order to mobilize, motivate, train and regularly supervise the municipal units. Another related problem arises from the usual political instability of local (municipal) administrations, which puts the sustainability of surveillance activities at risk. In terms of vector control, if epidemiological surveillance were to be prematurely relaxed, the consequences could be severe because of progressive reestablishment of foci of active transmission, caused not only by vector population recovery but also by invasion of homes by secondary and sylvatic species ${ }^{67}$.

Other biological and contextual situations will be involved in the future of Chagas disease and its control. For example, an important speculative question emerges from the possible introduction of different Trypanosoma cruzi groups in a given area, as a result of ecological and human activity changes, which may favor different patterns of morbidity ${ }^{6}{ }^{9}$. From the sociological point of view, one very fundamental obstacle to overcoming the disease will remain in the form of so-called sick houses (La casa enferma), as so well described by Briceño León ${ }^{1}$ : infested rural huts constitute an isolated context of poverty with a low political profile and very low quality of life. Sick houses do not stimulate self-reliance, and likewise do not bring happiness. The same context can be discussed in relation to the migration of people with Chagas disease from rural areas to cities. The condition of their shanties is quite similar to (or worse than) to their original huts. In this respect, it needs to be recognized that appropriate continuing policies for rural dwellings have been neglected throughout Latin America over recent decades, in spite of some exceptions observed in Venezuela and Uruguay. The key point involved in this can probably be explained by sociological and political factors involving the strong tendency towards urbanization and the lack of political significance of people living in rural areas $^{15}$.

Alongside blood transfusion, endemic programs are progressing well, with very little chance of occurrences of new cases of transfusional Chagas disease. Improvement in blood donor selection is still required in some parts of Bolivia, Costa Rica and Mexico, according to $\mathrm{WHO}^{10}{ }^{14}$. Given the progressive decreases in the numbers of infected blood donors as a medium-term consequence of vector control, it is expected that blood bank control must continue for about twenty years more in endemic countries. For this period, a series of challenges and constraints must be present within the working agenda of healthcare authorities and researchers. The key points involved will contribute towards maintaining donor control, in terms of cost benefit, as well as enabling desirable improvements in serological tests, in terms of their maximum sensitivity and specificity. Such research is also expected to provide a new perspective regarding universal chemoprophylaxis ${ }^{4811}$.

In terms of congenital transmission, the expected tendency seems to be a progressive decline in the numbers of infected fertile women in the areas with effective and continuous vector control. This trend is clearly observed in Brazil and Uruguay, where the incidence of congenital disease is becoming ever lower, in parallel with displacement of the infection to older age groups of mothers ${ }^{36}$. With regard to program implementation, in some areas of Paraguay, Argentina, Brazil and Bolivia, pregnant 
women from endemic areas are undergoing serological screening for Trypanosoma cruzi antibodies, thus making it easier to find newborns presenting Chagas disease. This is an ambitious (and expensive) program that may provide not only better medical care for the mothers, but also early and effective detection and treatment for eventual Chagas-positive babies. The problem, again, lies in the cost-benefit relationship as well as the lack of medical and laboratory expertise in endemic areas.

Finally, considering morbidity and mortality, a variety of data indicate that the medical impact of the disease has been decreasing over recent decades. The reasons for this seem to be complex and multifactorial, deserving careful multicenter analysis. The migration of millions of infected individuals to urban centers may have given rise to better medical attention, reduced physical effort, interruption of exogenous reinfection and other possible causative parameters. Nevertheless, the continuing existence of 12 to 15 million infected individuals does not allow healthcare professionals and authorities to merely take a contemplative attitude over the coming decades. One of the most urgent tasks in the new millennium simply remains the provision of medical care for people with Chagas disease, particularly for those suffering from chronic cardiopathy ${ }^{2} 314$

In terms of future situations, the coming decades probably will be characterized by a progressive reduction and focusing of domestic vector populations, following predictable changes in sylvatic ecotopes (jigsaw puzzle and concentration) and reductions in rural human populations. Disease transmission through transfusions will probably come completely under control (consolidation), but cases of congenital transmission may still occur, in spite of progressive reductions. Orally transmitted cases are likely to continue to appear in different ecological settings, generally linked with natural foci of American trypanosomiasis. A progressive reduction in human Chagas disease prevalence is expected in endemic areas, correlating with control activities and with mortality among individuals who are already infected. Consequently, the social and political visibility of the disease is expected to decrease, along with its priority for control and research ${ }^{2} 3613$

In summary, virtual elimination of human Chagas disease can be considered to be an attainable goal, but we still are at risk. A series of crucial additional questions will need to be addressed in the near future, such as:

- Is it possible to maintain the critical mass of research and services? For how long?

- Is it possible for a new malaria-like situation to occur within this history?
- How will greater references for national programs be maintained, taking healthcare decentralization, political weakness and decreased priority into consideration?

- Who will be the main protagonists and what will be the central agenda for the next two decades?

- What have been the principal successes and the lessons from failure within this history of control, healthcare services and research?

- What should our best legacy be for the next generations of citizens, researchers and politicians?

\section{REFERENCES}

1. Briceño-León R. La Casa Enferma. Sociología de la Enfermedad de Chagas. Ediciones Capriles, Caracas, p. 153, 1990.

2. Dias JCP. Chagas disease: successes and challenges. Editorial. Cadernos de Saúde Pública 22: 2021, 2006.

3. Dias JCP. Southern Cone Initiative for the elimination of domestic populations of Triatoma infestans and the interruption of transfusional Chagas disease. Historical aspects, present situation and perspectives. Memórias do Instituto Oswaldo Cruz 102 (supl I): 11-18, 2007.

4. Dias JCP, Schofield CJ. Controle da transmissão transfusional da doença de Chagas na Iniciativa do Cone Sul. Revista da Sociedade Brasileira de Medicina Tropical 31: 373-383, 1998.

5. Dias JCP, Schofield CJ. The evolution of Chagas Disease (American Trypanosomiasis) control after 90 years since Carlos Chagas discovery. Memórias do Instituto Oswaldo Cruz 94 (supl I): 103-121, 1999.

6. Dias JCP, Silveira AC \& Schofield CJ. The impact of Chagas Disease control in Latin America. A Review. Memórias do Instituto Oswaldo Cruz 97: 603-612, 2002.

7. Moraes-Souza H. Transmissão transfusional da doença de Chagas. Revista de Patologia Tropical 29 (supl 1): 91-100, 2000.

8. Pirard M, Lihoshi N, Boelaert M, Basanta P, Lopez F, Van der Stuyft P. The validity of serologic tests for Trypanosoma cruzi and the effectiveness of transfusional screening strategies in a hyperendemic region. Transfusion 45: 554-561, 2005.

9. Prata AR. Clinical and epidemiological aspects of Chagas disease. Lancet Infectious Disease 7: 572-100, 2001.

10. Salvatella R. Achievements in controlling Chagas disease in Latin America. Conference in Geneva (WHO). July 6, 2007.

11. Schmunis GA, Zicker F, Cruz JR, Cuchi P. Safety of blood supply for infectious diseases in Latin American countries. The American Journal of Tropical Medicine and Hygiene 65: 924-930, 2001.

12. Schofield CJ, Dias JCP. The Southern Cone Initiative against Chagas Disease. Advances in. Parasitology 42: 2-29, 1999.

13. Senior K. Chagas disease: moving towards global elimination. Lancet Infectious Diseases 7: 572-581, 2007.

14. World Health Organization. Control of Chagas Disease. WHO Technical Report Series 905. Geneva, World Health Organization, 2002. 